\title{
Pengaruh Motivasi Belajar Terhadap Prestasi Belajar Matematika Siswa Kelas VIII SMPN 1 Kuala Behe
}

\author{
Rahmat Winata $^{1 *}$, Rizki Nurhana Friantini ${ }^{2}$ \\ 1,2 Program Studi Pendidikan Matematika, STKIP Pamane Talino. \\ Jalan Afandi Rani, Ngabang, Kalimantan Barat, Indonesia. \\ *E-mail: nata_win89@yahoo.com, Telp: +6285752996059
}

Article received : 04-01-2019, article revised : 27-02-2019, article published: 31-03-2019

DOI : $10.25273 /$ jipm.v7i2.3663

\begin{abstract}
Abstrak
Tujuan penelitian ini untuk mengetahui pengaruh motivasi belajar terhadap prestasi belajar matematika siswa kelas VIII SMP Negeri 1 Kuala Behe Tahun Ajaran 2018/2019 Kabupaten Landak. Jenis penelitian ini adalah kuantatif dengan pendekatan ex post facto. Populasi semua siswa Kelas VIII SMP Negeri 1 Kuala Behe. Jumlah sampel pada penelitian ini adalah sebanyak 64 siswa yang dipilih dengan menggunakan teknik sampling jenuh. Teknik analisis data menggunakan regresi linear sederhana dengan uji prasyarat yaitu normalitas dengan metode Kolmogorov-Smirnov, heteroskedastisitas dengan metode Glejser, linearitas dengan menggunakan test for linearity, Multikolonieritas dengan menggunakan Variance Inflation Factor (VIF), dan Outokorelasi dengan metode Durbin-Watson. Hasil penelitian menunjukkan terdapat pengaruh motivasi belajar terhadap prestasi belajar matematika siswa kelas VIII SMP Negeri 1 Kuala Behe Tahun Ajaran 2018/2019 Kabupaten Landak. Hasil R Square $=0,195 \times 100 \%=19,5 \%$ yang menunjukkan bahwa prestasi belajar matematika siswa kelas VIII SMP Negeri 1 Kuala Behe dapat dijelaskan oleh motivasi belajar sebesar $19,5 \%$.
\end{abstract}

Kata Kunci: Motivasi Belajar; Prestasi Belajar; Matematika

\section{The Effect Of Learning Motivation On Mathematics Learning Achievement Of Eighth Grade Students Of SMP N 1 Kuala Behe}

\begin{abstract}
The purpose of this study was to determine the effect of learning motivation on mathematics learning achievement of eighth grade students of SMP N 1 Kuala Behe acedemic year of 2018/2019 Landak Regency. This type of research was quantitative with ex post facto approach. The population of all eighth grade students at SMP N 1 Kuala Behe. The number of sample in this study was 64 students who were selected using saturated sampling technique. The data analysis technique used simple linear regressionwith prerequisite test namely normality of Kolmogorov-Smirnov method, heteroscedasticity of Glejser method, linearity using test for linearity, multicolonity using Variance Inflation Factor (VIF), and autocorrelation of Durbin-Watson method. The result shows that there is an effect of learning motivation on mathematics learning achievement of eighth grade students of SMP N 1 Kuala Behe academic year 2018/2019 Landak Regency. The result of R square $=0,915 \times 100 \%=$ $19,5 \%$ which indicates that the mathematics learning achievement of eighth grade students of SMP N 1 Kuala Behe can be explained by learning motivation of $19,5 \%$.
\end{abstract}

Keywords: Learning Motivation; Learning Achievement; Mathematic 


\section{PENDAHULUAN}

Matematika merupakan salah satu mata pelajaran wajib yang penting untuk dipelajari dan dikuasai siswa. Hal tersebut dikarenakan matematika merupakan mata pelajaran yang bermanfaat sepanjang hidup. Beberapa manfaat yang diperoleh dari matematika seperti ke-mampuan berhitung yang pasti kita gunakan dalam kehidupan kita seharihari, selain itu juga konsep mengenai untung, rugi, dan diskon yang kita terapkan pada saat jual beli, serta berbagai manfaat lainnya. Menurut Imoko dan Agwagah (Uchechi, 2013, p.848), Matematika adalah salah satu mata pelajaran yang mendorong peserta didik untuk mengamati, merefleksikan, dan mempertimbangkan secara logis masalah dan dalam mengkomunikasikan ide, menjadikannya disiplin intelektual sentral dan alat vital dalam sains, perdagangan, dan teknologi. Di-karenakan banyaknya manfaat yang diperoleh dari pembelajaran matematika, sudah seharusnya siswa mempelajari matematika di sekolah dan menguasainya. Dalam mempelajari matematika di sekolah diperoleh hasil akhir yang menunjukkan berapa tingkat penguasan siswa mengenai matematika yang disebut dengan prestasi belajar matematika.

Prestasi belajar adalah peningkatan hasil usaha kegiatan belajar yang dinyatakan dalam bentuk simbol, angka, huruf, maupun kalimat yang dapat mencerminkan hasil yang sudah dicapai oleh setiap anak dalam periode tertentu (Handayani, 2016, p.143). Selanjutnya menurut prestasi adalah hasil akhir dari pengalaman belajar, apa yang telah diperoleh siswa sebagai hasil dari apa yang mereka miliki. Sedangkan prestasi matematika terutama berkaitan dengan kesempurnaan siswa dalam tes yang dibuat oleh guru atau tes prestasi standar yang dikelola oleh lembaga (Nizoloman, 2013, p.2231). Reddy (Bosman dan Schulze, 2018, p.1) menyatakan bahwa prestasi pada bidang matematika merupakan indikator dasar dari kinerja sistem persekolahan di berbagai negara. Selain itu prestasi siswa dalam Matematika memiliki efek tidak hanya untuk kehidupan pribadi dan profesional siswa tetapi juga untuk pembangunan nasional (Murray, 2013, p.150). Dari pendapat tersebut dapat disimpulkan bahwa prestasi belajar matematika penting bukan hanya bagi siswa itu sendiri tetapi bila dilihat lebih jauh lagi dapat juga memberikan efek pada pembangunan suatu negara, misal di Indonesia. Oleh karena itu, prestasi belajar matematika yang dicapai siswa memerlukan perhatian lebih dari pihak-pihak yang terlibat.

Dari hasil observasi diketahui bahwa prestasi belajar siswa kelas VIII SMP Negeri 1 Kuala Behe pada mata pelajaran matematika belum mencapai KKM. Yaitu diperoleh rata-rata nilai ulangan harian hanya mencapai 61 masih di bawah KKM sebesar 75. Hal ini tentunya bukan merupakan hasil yang diharapkan. Dari hasil observasi juga diperoleh bahwa metode yang digunakan guru pada pembelajaran matematika adalah metode pembelajaran konvensional yaitu secara ceramah. Metode pembelajaran ini sangat berpusat pada guru dan kurang memberikan kesempatan kepada siswa untuk berperan aktif dalam pembelajaran, sehingga siswa pasif dan tidak termotivasi selama pembelajaran matematika. Hal tersebut sesuai dengan pendapat Solina dkk (2013, p.289) yang menyatakan bahwa motivasi belajar siswa berkaitan dengan berbagai faktor, seperti materi belajar, bakat siswa, kemenarikan penyajian oleh guru, suasan belajar, faktor teman sebaya, dan faktor orangtua.

Motivasi berpangkal dari kata motif yang dapat diartikan sebagai daya penggerak yang ada di dalam diri seseorang untuk melakukan aktivitas-aktivitas tertentu demi 


\section{JIPM (Jurnal Ilmiah Pendidikan Matematika), 7(2), Maret 2019- 87}

Rahmat Winata, Rizki Nurhana Friantini

tercapainya suatu tujuan. Sedangkan motivasi diartikan dengan kondisi psikologis yang mendorong seseorang untuk melakukan sesuatu (Fathurrohman dan Sutikno, 2011, p.19). Selanjutnya motivasi belajar dengan suatu daya, dorongan atau kekuatan, baik yang datang dari diri sendiri maupun dari luar yang mendorong peserta didik untuk belajar (Lestari dan Mokhammad, 2017, p.93). Kemudian motivasi belajar adalah dorongan internal dan eksternal pada peserta didik yang sedang belajar untuk mengadakan perubahan perilaku (Suprijono, 2012, 163). Oleh karena itu yang dimaksud dengan motivasi belajar adalah dorongan atau kekuatan yang menggerakan seseorang untuk melaksanakan kegiatan belajar.

Motivasi dibagi menjadi dua yaitu 1) motivasi intrinsik yaitu motivasi yang timbul dari dalam individu sendiri tanpa ada paksaan dorongan orang lain, tetapi atas dasar kemauan sendiri, sedangkan 2) motivasi ekstrinsik yaitu motivasi yang timbul sebagai akibat pengaruh dari luar individu (Fathurrohman dan Sutikno, 2011, p.19-20). Sedangkan untuk indikator motivasi belajar sebagai berikut: 1) adanya dorongan dan kebutuhan belajar, 2) menunjukkan perhatian dan minat terhadap tugas-tugas yang diberikan, 3) tekun menghadapi tugas, 4) ulet menghadapi kesulitan, 5) adanya hasrat dan keinginan berhasil (Lestari dan Mokhammad, 2017, p.93).

Oleh karena motivasi belajar adalah dorongan untuk melaksanakan kegiatan belajar maka diduga motivasi belajar mempengaruhi prestasi belajar. Menurut Prastya Irawan dkk berdasarkan hasil penelitian terdapat tiga faktor yang mempengaruhi prestasi belajar yaitu latar belakang keluarga, kondisi atau konteks sekolah, dan motivasi (Suprijono, 2012, p.162). Selanjutnya menurut hasil penelitian hubungan antara motivasi belajar dan prestasi belajar matematika dikategorikan sangat tinggi. Hubungan yang terjadi adalah hubungan yang positif yang signifikan antara motivasi belajar dan prestasi belajar, sehingga dapat dikatakan apabila motivasi belajar naik maka prestasi belajar matematika siswa pun akan naik (Soewono, 2018, p.23). Oleh karena itu, akan dilihat pada penelitian ini apakah terdapat pengaruh antara motivasi belajar terhadap prestasi belajar matematika pada siswa kelas VIII SMP Negeri 1 Kuala Behe tahun ajaran $2018 / 2019$

\section{METODE}

Penelitian ini dilaksanakan di SMP Negeri 1 Kuala Behe pada semester ganjil tahun ajaran 2018/2019. Populasi terdiri dari siswa kelas VIII SMP Negeri 1 Kuala Behe tahun ajaran 2018/2019 yang terdiri dari dua kelas yaitu kelas VIIIA dan VIIIB. Jumlah siswa kelas VIIIA dan VIIIB sama yaitu sebesar 32 siswa sehingga total populasi sebesar 64 siswa.

Jenis penelitian ini adalah penelitian kuantitatif dengan pendekatan ex post facto, peneliti tidak dapat secara langsung memanipulasi variabel bebas. Disebut dengan metode penelitian kuantitatif karena data penelitian berupa angka-angka dan analisis menggunakan statistik (Sugiyono, 2010, p.13). Penelitian ex post facto merupakan penelitian dimana variabel-variabel bebas telah terjadi ketika peneliti mulai dengan pengamatan variabel terikat dalam suatu penelitian. Pada penelitian ini, keterikatan antarvariabel bebas dengan variabel bebas, maupun antarvariabel bebas dengan terikat sudah terjadi secara alami, dan peneliti dengan setting tersebut ingin melacak kembali jika dimungkinkan apa yang menjadi faktor penyebabnya (Sukardi, 2016, p.165). 


\section{JIPM (Jurnal Ilmiah Pendidikan Matematika), 7(2), Maret 2019- 88}

Rahmat Winata, Rizki Nurhana Friantini

Teknik analisis data menggunakan analisis regresi yaitu analisis regresi linier sederhana. Analisis regresi digunakan dalam rangka untuk melakukan prediksi. Tujuan analisis regresi ialah menentukan model statistik yang dapat dipakai untuk memprediksi nilai-nilai variabel terikat berdasarkan nilai-nilai dari variabel bebas (Budiyono, 2009, p.251). Sedangkan analisis regresi linier sederhana merupakan bagian dari analisis regresi yang bertujuan untuk menganalisis hubungan linier antara dua variabel (Lestari dan Mokhammad, 2017, p.323).

Variabel yang digunakan dalam penelitian ini terdiri dari variabel bebas yaitu motivasi belajar dan variabel terikat yaitu prestasi belajar matematika. Metode pengumpulan data penelitian meliputi metode tes dan angket. Populasi dalam penelitian ini adalah semua siswa Kelas VIII SMP Negeri 1 Kuala Behe. Jumlah sampel pada penelitian ini adalah sebanyak 64 siswa yang dipilih dengan menggunakan teknik sampling jenuh. Sampling jenuh adalah teknik penentuan sampel bila semua anggota populasi digunakan sebagai sampel (Lestari dan Mokhammad, 2017, p.111).

Untuk instrumen penelitian ada dua yaitu 1) instrumen angket digunakan untuk memperoleh data mengenai motivasi belajar siswa. Instrumen angket dibuat sebanyak 32 butir pernyataan dengan masing-masing 16 butir pernyataan positif dan negatif. Butir pernyataan pada angket dibuat sesuai dengan indikator motivasi belajar. Instrumen angket terlebih dahulu diuji coba untuk dilihat validitas, reliabilitas, dan konsistensi internal butir angket. 2) instrumen tes digunakan untuk memperoleh data prestasi belajar siswa. Instrumen tes dibuat sebanyak 35 butir soal dalam bentuk pilihan ganda. Instrumen tes dibuat berdasarkan indikator dari pokok bahasan Pola Bilangan. Untuk instrumen tes dilakukan uji coba dan dilihat validitas, reliabilitas, daya pembeda, dan tingkat kesukaran.

Butir yang layak pada instrumen angket dan tes kemudian diberikan kepada semua siswa kelas VIII SMP Negeri 1 Kuala Behe. Pada data hasil tes dan angket dilakukan uji prasyarat meliputi uji normalitas menggunakan metode KolmogorovSmirnov, heteroskedastisitas dengan metode Glejser, outokorelasi dengan metode DurbinWatson, multikolinieritas dengan menggunakan metode Variance Inflation Factor (VIF), dan linearitas menggunakan test for linearity. Setelah semua uji prasyarat teleh dipenuhi selanjutnya dilakukan uji hipotesis menggunakan analisis regresi linear sederhana.

\section{HASIL DAN PEMBAHASAN}

Dari hasil uji coba angket diperoleh butir pernyataan yang layak untuk digunakan sebanyak 24 butir yang terdiri dari 12 butir pernyataan positif dan 12 butir pernyataan negatif. Untuk 8 butir pernyataan yang lain tidak layak dikarenakan tidak memenuhi syarat konsistensi internal. Selanjutnya dari hasil uji coba tes diperoleh butir soal yang layak untuk digunakan sebanyak 30 butir soal. 5 butir soal yang lain tidak layak dikarenakan tidak memenuhi syarat pada uji daya pembeda dan uji tingkat kesukaran. Pada uji daya pembeda yaitu 2 butir soal pada kriteria jelek dan 3 butir soal pada kriteria sangat jelek. Sedangkan uji tingkat kesukaran yaitu 5 butir soal pada kriteria sukar.

Setelah intrumen diberikan kepada sampel dan diperoleh data, selanjutnya data tersebut dianalisis. Sebelum masuk ke uji hipotesis dilakukan uji prasyarat terlebih dahulu. Uji prasyarat yang dilakukan sebanyak 5 syarat yaitu sebagai berikut. 
Untuk uji normalitas dilakukan dengan metode Kolmogorov-Smirnov berbantuan SPSS. Hipotesis untuk uji normalitas data sebagai berikut:

$\mathrm{H}_{0}$ : Data berasal dari populasi yang berdistribusi normal
$\mathrm{H}_{1}$ : Data berasal dari populasi yang berdistribusi tidak normal

Hasil uji normalitas dapat dilihat pada Tabel 1 berikut.

Tabel 1. One-Sample Kolmogorov-Smirnov Test

\begin{tabular}{llr}
\hline & & Standardized Residual \\
\hline $\mathrm{N}$ & & 64 \\
Normal Parameters & Mean & $0 \mathrm{E}-7$ \\
& Std. &, 99203175 \\
& Deviation & \\
Most Extreme & Absolute &, 142 \\
Differences & Positive &, 073 \\
& Negative &,- 142 \\
Kolmogorov-Smirnov Z & & 1,135 \\
Asymp. Sig. (2-tailed) & &, 152 \\
\hline a. Test distribution is Normal. & \\
b. Calculated from data. &
\end{tabular}

Kriteria pengujian hipotesisnya pada taraf signifikansi $5 \%$ atau $\alpha=0,05$ adalah $\mathrm{H}_{0}$ diterima jika angka signifikansi (sig) $>\alpha$ maka data berdistribusi normal. Dari Tabel 1 dapat dilihat bahwa nilai sig yang diperoleh dari hasil uji normalitas dengan menggunakan metode Kolmogorov-Smirnov sebesar 0,152 lebih dari 0,05 ( $\mathrm{sig}=0,152>0,05$ ) sehingga $\mathrm{H}_{0}$ diterima. Oleh karena itu dapat disimpulkan bahwa data berasal dari populasi yang berdistribusi normal.
Untuk uji heteroskedastisitas dilakukan dengan Metode Glejser berbantuan SPSS. Hipotesis untuk uji heteroskedastisitas sebagai berikut:

$\mathrm{H}_{0}$ : Model tidak mengandung gejala heteroskedastisitas

$\mathrm{H}_{1}$ : Model mengandung gejala heteroskedastisitas

Hasil uji heteroskedastisitas dapat dilihat pada Tabel 2.

Tabel 2. Hasil uji heteroskedastisitas

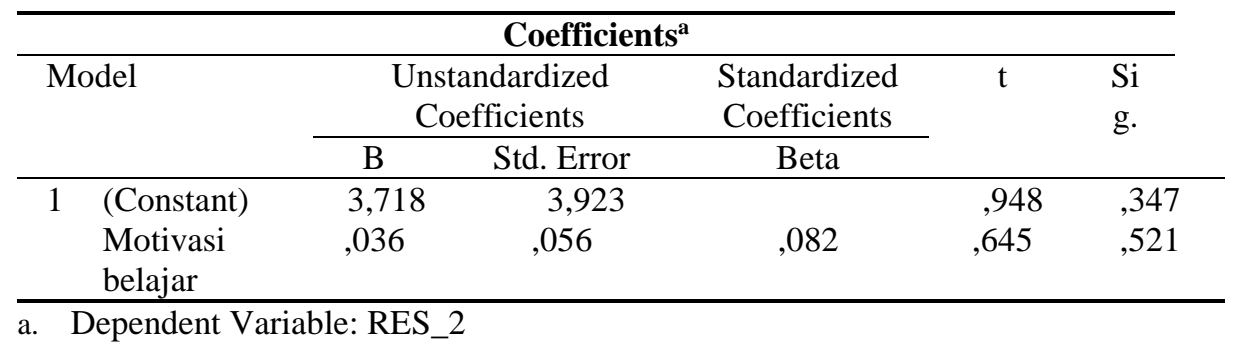

Dapat dilihat pada tabel di atas bahwa nilai sig. dari variabel motivasi sebesar 0,521 lebih besar dari $0,05 \quad(0,521>0,05)$ maka $\mathrm{H}_{0}$ diterima. Hal ini berarti model regresi tidak mengandung gejala heteroskedastisitas.
Untuk uji outokorelasi dilakukan dengan metode Durbin-Watson berbantuan SPSS. Jika nilai pada tabel Durbin-Watson lebih dari dU dan kurang dari $4-\mathrm{dU}$ maka tidak 
terdapat outokorelasi. Hasil uji outo-korelasi dapat dilihat pada Tabel 3.

Tabel 3. Hasil uji outokorelasi

\begin{tabular}{cccccc}
\hline Model & \multicolumn{5}{c}{ Model Summary $^{\mathbf{b}}$} \\
& $\mathrm{R}$ & $\begin{array}{c}\mathrm{R} \\
\text { Adjusted R } \\
\text { Square }\end{array}$ & $\begin{array}{c}\text { Std. Error of } \\
\text { the Estimate }\end{array}$ & $\begin{array}{c}\text { Durbin- } \\
\text { Watson }\end{array}$ \\
\hline 1 &, $442^{\mathrm{a}}$ &, 195 &, 182 & 7,50223 & 2,308 \\
\hline
\end{tabular}

a. Predictors: (Constant), motivasi belajar

b. Dependent Variable: prestasi belajar

Dapat dilihat pada Tabel 3 bahwa nilai Durbin-Watson (d) sebesar 2,308. Untuk dU $<\mathrm{d}<4$-dU maka $1,629<\mathrm{d}<2,371$, sedangkan nilai $\mathrm{d}=2,308$ sehingga $\mathrm{d}$ terletak diantara dU dan 4-Du $(1,629<\mathrm{d}=$ $2,308<2,371)$. Dapat disimpulkan model persamaan regresi tidak terdapat outokorelasi.
Untuk uji multikolinieritas dengan menggunakan metode Variance Inflation Factor (VIF) berbantuan SPSS. Jika nilai $V I F<10$ maka tidak terdapat gejala multikolinier. Hasil uji multikolinieritas dapat dilihat pada Tabel 4.

Tabel 4. Hasil uji multikolinieritas

\begin{tabular}{lcccccc}
\hline & & \multicolumn{4}{c}{ Coefficients $^{\mathbf{a}}$} & \multicolumn{2}{c}{} \\
& Model & \multicolumn{2}{c}{ Unstandardized Coefficients } & Std. Coeff & \multicolumn{2}{c}{ Collinearity Statistics } \\
& & B & Std. Error & Beta & Tolerance & VIF \\
\hline 1 & $\begin{array}{c}\text { (Const.) } \\
\text { Motivasi } \\
\text { belajar }\end{array}$ & 48,009 & 7,331 & & 1,000 & 1,000 \\
&, 407 &, 105 &, 442 & & \\
\hline a. & Dependent Variable: prestasi belajar & & &
\end{tabular}

Dapat dilihat pada tabel di atas nilai VIF (Variance Inflation Factor) sebesar 1. Oleh karena VIF $=1$ tidak lebih dari 10 $(\mathrm{VIF}=1<10)$ maka model dinyatakan tidak terdapat gejala multikolinier.
Untuk uji linieritas dengan menggunakan test for linearity dengan hipotesis sebagai berikut:

$\mathrm{H}_{0}$ : Model regresi linear

$\mathrm{H}_{1}$ : Model regresi tidak linear

Hasil uji linieritas dapat dilihat pada Tabel 5.

Tabel 5. Hasil uji linieritas

\begin{tabular}{lllrrr}
\hline & ANOVA Table & & & \\
& & df & F & Sig. \\
\hline $\begin{array}{l}\text { Prestasi } \\
\text { belajar } * \\
\text { motivasi }\end{array}$ & Between Groups & (Combined) & 25 & 2,028 &, 024 \\
& Linearity & 1 & 17,33 &, 000 \\
& & Deviation from & 24 & 1,390 &, 178 \\
& & Linearity & & & \\
& & & 38 & & \\
& Within Groups & & 63 & & \\
\hline
\end{tabular}

Dari tabel di atas dapat diperoleh nilai sig. untuk uji linieritas dengan menggunakan uji F sebesar 0,178 lebih besar dari 0,05 (sig.= $0,178>0,05)$ maka $\mathrm{H}_{0}$ diterima. Hal ini berarti model regresi linear.
Dari penjelasan di atas dapat disimpulkan bahwa uji prasyarat semua telah terpenuhi. Setelah semua uji prasyarat terpenuhi selanjutnya dilakukan uji hipotesis menggunakan regresi linear sederhana. Berikut hasil dari analisis regresi. 
Tabel 6. Persamaan Regresi

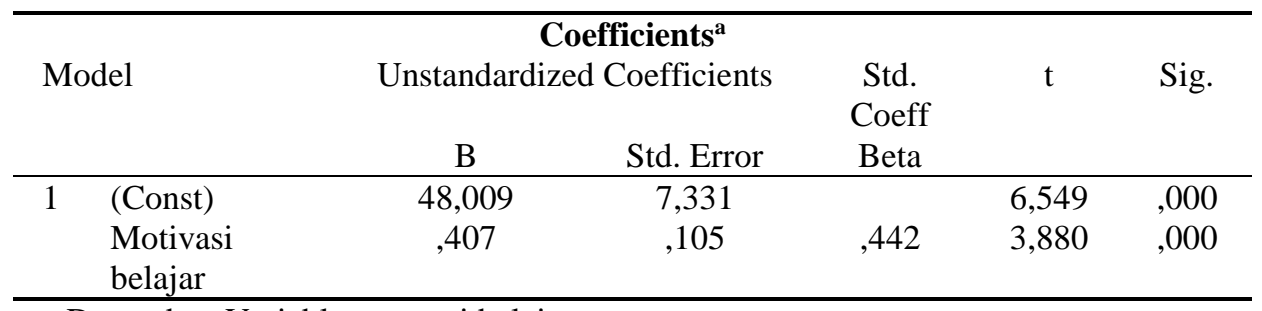

a. Dependent Variable: prestasi belajar

Berdasarkan hasil analisis dengan menggunakan SPSS 20.0 pada Tabel 6 diperoleh harga $b_{0}=48,009$ dan $b_{1}=0,407$ dimana $b_{1}$ merupakan koefisien dari variabel $\mathrm{X}_{1}$ sehingga dapat disusun dalam persamaan regresi dugaan yaitu :

$$
\hat{Y}=48,009+0,407 \mathrm{X}_{1}
$$

Dari persamaan regresi di atas, harga konstanta sebesar 48,009 menyatakan bahwa jika tidak ada motivasi belajar maka prestasi belajar matematika siswa adalah 48,009. Koefisien regresi $X_{1}$ sebesar 0,407 menyatakan bahwa setiap perubahan motivasi belajar siswa sebesar 1 satuan maka akan meningkatkan prestasi belajar matematika sebesar 0,407 satuan.

Kemudian menguji keberartian model regresi dugaan yang telah diperoleh menggunakan uji $t$, dengan hipotesis yang dirumuskan sebagai berikut:

$\mathrm{H}_{0}: \beta=0$

$\mathrm{H}_{1}: \beta \neq 0$

Kriteria pengujian adalah $\mathrm{H}_{0}$ ditolak jika sig $<\alpha$. Berdasarkan hasil analisis dengan menggunakan SPSS 20.0 pada Tabel 6, diperoleh sig $=0,000$ dan $\alpha=0,05$. Karena sig $<\alpha$ maka $\mathrm{H}_{0}$ ditolak, artinya $\beta \neq 0$ dan disimpulkan bahwa model regresi dugaan yang diperoleh adalah berarti. Hal ini menunjukkan motivasi mempengaruhi prestasi belajar matematika pada siswa kelas VIII SMP Negeri 1 Kuala Behe tahun ajaran 2018/2019.

Tabel 7. Koefisien Determinasi

\begin{tabular}{lrrrr}
\hline \multicolumn{4}{c}{ Model Summary } \\
Model & $\mathrm{R}$ & $\mathrm{R}$ Square & $\begin{array}{c}\text { Adjusted R } \\
\text { Square }\end{array}$ & $\begin{array}{c}\text { Std. Error of the } \\
\text { Estimate }\end{array}$ \\
\hline 1 &, $442^{\mathrm{a}}$ &, 195 &, 182 & 7,50223 \\
\hline a. Predictors: (Constant), motivasi belajar & &
\end{tabular}

Selanjutnya menghitung koefisien determinasi yaitu angka yang digunakan untuk melihat suatu ukuran seberapa tepat model regresi linear dugaan dapat menjelaskan hubungan linearnya antara variabel pada $X_{1}$ dengan $Y$. Berdasarkan hasil analisis dengan menggunakan program SPSS 20.0 pada Tabel 7, R Square $=0,195 \mathrm{x}$ $100 \%=19,5 \%$ yang menunjukkan bahwa prestasi belajar matematika siswa kelas VIII
SMP Negeri 1 Kuala Behe dapat dijelaskan oleh motivasi belajar sebesar 19,5\% sisanya $81,5 \%$ dijelaskan oleh faktor lain yang tidak diteliti dalam penelitian ini.

\section{SIMPULAN}

Berdasarkan hasil penelitian, dapat disimpulkan bahwa terdapat pengaruh motivasi belajar terhadap prestasi belajar matematika pada siswa kelas VIII SMP Negeri 1 Kuala 
Behe tahun ajaran 2018/2019. Dari hasil R Square $=0,195 \times 100 \%=19,5 \%$ menunjuk-

\section{DAFTAR PUSTAKA}

Bosman, Anne dan Schulze Salome. (2018). Learning Style Preferences and Mathematics Achievement of Secondary School Learners. South African Journal of Education. Vol. 38, No. 1, February 2018.

Budiyono. (2009). Statistika untuk Penelitian. Surakarta: UNS Press.

Fathurrohman, Pupuh dan Sobry Sutikno. (2011). Strategi Belajar Mengajar: Strategi Mewujudkan Pembelajaran Bermakna Melalui Penanaman Konsep Umum \& Islami. Bandung: PT Refika Aditama.

Handayani, Santy. (2016). Pengaruh Perhatian Orangtua dan Minat Belajar Matematika terhadap Prestasi Belajar Matematika Siswa. Jurnal Formatif. Vol. 6, No. 2, hal. 141-148. ISSN 2088-351X.

Lestari, Karunia Eka dan Mokhammad Ridwan Yudhanegara. (2017). Penelitian Pendidikan Matematika. Bandung: PT Refika Aditama.

Murray, Jacqueline. (2013). The Factors that Influence Mathematics Achievement at the Barbice Campus. International Journal of Business and Social Science. Vol. 4, No. 10, Special IssueAugust 2013.

Nizoloman, Obdual Nabhel. (2013). Relationship Between Mathematical Ability and Achievement in Mathematics Among Female Secondary School kan bahwa motivasi belajar mempengaruhi prestasi belajar matematika sebesar 19,5\%.

Students in Bayelsa State Nigeria. Procedia Social and Behavioral Sciences. 106, 2230-2240.

Soewono, Eddy Bambang. (2018). Pengaruh Motivasi Belajar terhadap Prestasi Belajar Matematika Menggunakan ELearning Pendekatan Bimbingan Belajar Berbasis Multimedia. IKRAITHInformatika Vol. 2, No. 2, Juli 2018.

Sugiyono. (2010). Metode Penelitian Pendidikan: Pendekatan Kuantitatif, Kualitatif, dan $R \& D$. Bandung: Alfabeta.

Sukardi. (2016). Metodologi Penelitian Pendidikan Kompetensi dan Praktiknya. Jakarta: Bumi Aksara.

Suprijono, Agus. (2012). Cooperative Learning: Teori \& Aplikasi PAIKEM. Yogyakarta: Pustaka Pelajar.

Ucheci E., Ihendinihu. (2013). Enhancing Mathematics Achievement of Secondary School Students Using Mastery Learning Approach. Journal of Emerging Trends in Educational Research and Policy Studies. Vol. 4, No. 6, pp 848-854. ISSN 2141-6990. 